\title{
Integration Model of Learning Religion and Science in Madrasah Based on the Tahfizh Al-Qur'an Pesantren
}

\author{
Choeroni $^{1}$, Fattah Syukur ${ }^{2}$, Hamdan Hadi Kusuma ${ }^{3}$ \\ Sultan Agung Islamic University, Semarang, Indonesia ${ }^{1}$, Walisongo Islamic University, \\ Semarang, Indonesia ${ }^{2,3}$ \\ \{choeroni@unissula.ac.id ${ }^{1}$,fsyukur@walisongo.ac.id², hamdahhk@walisongo.ac.id ${ }^{3}$ \}
}

\begin{abstract}
This article discusses the science learning model in madrasas based on the tahfizh Al-Qur'an, namely MA Yanbu'ul Qur'an Menawan Kudus. This study aims to examine the science learning model in madrasas so that in the end it can be used as a science learning model for educational institutions based on the tahfizh al-Qur'an and have an impact on the development of traditional Islamic boarding school models in producing tafaqquh fiddin ulama, hafizh AlQur'an which is not only capable in the field of syar'i science but also mastering technology, especially in the field of natural science. The method used in this research is field research with a descriptive qualitative approach. The results showed that science learning at MA Yanbu'ul Qur'an Menawan showed creativity and innovation-solutions in the framework of integration of Islam and science as well as integrating the models of madrasah and Islamic boarding schools tahfizh Al-Qur'an. The integration framework refers to one of the three integration concepts, namely the Islamization of Science, Islamic Sciences, and Islamic Sciences which is supported by strengthening the mastery of natural science, the strength of foreign language ownership, and the memorization of the Qur'an.
\end{abstract}

Keywords: Integration; Science; Madrasah; Tahfizh Islamic Boarding School

\section{Introduction}

Learning in this 21 st-century madrasah is still difficult if we find madrasas that have a focus on learning natural science or natural science, both madrasas outside the Islamic boarding schools, madrasas based on salafiyah Islamic boarding schools, madrasas based on modern Islamic boarding schools especially those based on the tahfizh al Islamic boarding school. Because in general, these madrasas are more inclined towards deepening the science of fiqh, nahwu sharaf, tafsir, memorizing the Quran, or other sharia sciences. According to the explanation, it is necessary to develop a madrasa that is capable of being a model where in addition to madrasah providing learning of shari'ah science, focus on learning science also teaches students to memorize the Qur'an so that with this model it is hoped that students will be able to understand religious and science learning[1] at the same time memorizing the Qur'an. 
If we look at the madrasah model that is managed by the pesantren, especially the one with the modern pesantren, there will be several types and models that each one has preeminence. Several types and models at this time that are highly successful and become the foundation for Islamic education are schools based on the Quran and pesantren that is tahfizh al-Qur'an [2] In this Islamic education institution, apart from teaching Islamic education, it also teaches tahfizh al-Qur'an as its intellectual foundation. However, what has become a classic problem in the tahfizh al-Qur'an pesantren is that these institutions focus more on learning to memorize the Quran than other subjects, especially science-based lessons.

Besides, in this institution, foreign language skills such as Arabic and English are not well mastered, because in these institutions, apart from the national curriculum, only the pursuit of tahfizh al-Qur'an is essential. As the result, the ability of students in mastering natural science and foreign language skills is low or even less, this can be seen by alumni of the Tahfizh Islamic boarding school when they continue to study, on average they take humanities science majors and very few take natural science majors. Due to the projection of the pesantren's alumni is to become scholars who are experts in the field of shari'ah (Islamic law).[3]

Furthermore, tahfizh Islamic boarding schools can be grouped into three categories: first, studying the Quran and positioning it as a holy book but at the same time critically examining it with the main objective of exploring the meaning contained in it. This group places divine revelation in the heart and mind as a process of gaining an understanding of what is contained in it. With the latest methodologies including modern theories such as language, philosophy, literature. Second, the reviewer of the Qur'an with the title hafizh as the highest predicate. This group views that memorizing the Qur'an is the ultimate goal, there is no other scientific activity, it is unthinkable how to solve problems that occur in society by using the Qur'anic approach. Third, the Qur'anic reviewer who places the Qur'an as the holy word of Allah and reads it will receive worship. This group does not study the Qur'an with a critical method, nor does it place memorizing the Qur'an as the final goal. Within this group, there is a recognition that after memorizing the Qur'an it is easy to study other sciences as well as to make the heart feel at ease.[4] From the research conducted by Ramadani, the majority of tahfizh al-Qur'an institutions are in the second and third group categories, so there is hardly any tahfizh pesantren that is concerned with science and the development of contemporary sciences, especially the development of natural science as in the category.

The rapid development of science and technology in Indonesia on the one hand has increased material prosperity, but on the other hand, the paradigm of modern science and technology has dragged down the human dimension and spiritual and moral needs. The science and technology being developed are increasingly separating and leaving religion and ethics further away. This phenomenon shows that there is a sharp separation between the life of the world and the hereafter, which begins with a system education that is not integrated but is partially dichotomous. On the one hand, there is a traditional education system that specifically studies Islamic sciences in law, narrow and limited aspects of worship. On the other hand, there is an education system that emphasizes secular science which adopts the raw material given from the West. The two educational systems produce a duality of personality in the body of Islam and are contradictory. Therefore, it is necessary to adopt modern secular disciplines with Islamic insight, then reintegrate the knowledge that has been patterned in dichotomous Islamic education.[5]

The dichotomy in Islamic education occurs because of two conflicting thoughts, namely religion considers that the general knowledge learned is heretical or invalid. After all, it comes from unbelievers, while general science activists argue that theology is false science, or in other words as the mythology that will not reach a scientific level. This causes the distance 
between religious knowledge and general science to grow further. Therefore, the integration of religion and science is a solution that can be offered to answer this dichotomy of Islamic education. The integration of religion and science is an opportunity to improve the quality of Islamic education so that it continues to develop with human progress.[6] The existence of a focus on science education in Islamic educational institutions will be able to improve students 'abilities where in addition to understanding the science of sharia which is the science of fardlu' ain also has the ability in the field of science which is the science of fardlu kifayah. So that in the future students will be able to face and follow the times.

Islam does not recognize a dichotomy of knowledge, this is confirmed by the number of verses of the Qur'an that instruct people to seek knowledge and become scientists. The first verse that comes down, namely surah al-Alaq verses $1-5$ is the foundation of the integration of science, where the word iqra' when taken from the root word has various meanings such as conveying, examining, mentoring, researching, reading about something both expressed and implied. As for the object, the word reading command means something accessible to human reason. These comments reinforce that there is no dichotomy between religious and nonreligious knowledge in Islam.[7]

The development of Islamic education institutions, especially in education based on the tahfizh al-Qur'an pesantren, needs to have a tahfizh pesantren which has the initiative to make innovations, namely in addition to carrying out tahfizh al-Qur'an education for students it also combines bilingual skills; namely Arabic and English and the development of learning in the natural sciences through formal education. With this model, students are expected to be able to become strong intellectuals, where the basis of their intelligence is strong and supported by competent abilities in the field of science so that later they will be able to become strong Muslim scientists and memorize the Qu'ran.

\section{Discussion}

\subsection{Science Learning Model}

\section{a) Understanding Science Learning Model}

The word model in the Big Indonesian Dictionary means the pattern (example, reference, and variety) of something that will be produced or made. Another word for a model is something that is used as an example.[8] The term model is understood as a description or representation of reality. In a model, there is a set of variables that are interrelated in the pattern of relationships between one another so that the existing reality is easy to understand.

The word learning comes from the word learn which means the process of gaining understanding and how to interpret the world around students. In this sense, the meaning of learning means being focused on the attainment of quality thought and action to solve problems that are being and will be faced [9]. Meanwhile, the word science is defined as the science, which can mean natural science or humanities. In practice, learning science prioritizes students to be able to understand the natural surroundings scientifically. Learning science provides great opportunities for students to be able to understand the nature around them. To complement science learning, science learning is a combination of the experience of the scientific process and the understanding of science products in the form of direct experience.[10] 


\section{b) A paradigm of science learning}

To be able to adapt to the learning of science and technology in the 21 st century, it is necessary to rearrange the education and learning system, related to learning, there is a need for a shift in the learning paradigm which is originally teacher-centered (teaching-centered) to student-centered learning. (student-centered), where students learn to construct their abilities based on natural phenomena around them. The role of the teacher in learning at this time must shift to become a learning designer so that students actively seek new knowledge and as a facilitator or mediator for learning.[11]

Learning in this century should be more focused on developing the intellectual abilities of students to build understanding and knowledge independently in a social and cultural context. Learning tasks are designed in such a way as to attract the attention of students to be able to achieve high-level thinking skills, such as using laboratories as a source of science learning, the position of comics in science education, using field trips to increase participation, and science learning, using driving questions to motivate and maintain student interest in science learning.[12] Furthermore, the paradigm that is relevant to the demands of the current era is educational earning that has characters such as emphasizing learning how to learn (learning how to learn), prioritizing strategies that encourage and help students gain the ability to find answers or solutions to a question or problems with critical and creative thinking skills. To achieve this goal, the teacher must pay attention to the four pillars of education, namely learning to know, learning to do, learning to be and learning to be together or learning to socialize (learning to live together). [13]

\section{c) Science Learning Methods}

Integrated science teaching can be developed by several methods including through the lesson study, namely through measures steps include team shape lesson study; carry out the pre-development stage, namely the stage of making the learning model design; continued to pilot the design development phase with model learning as much as three times the test and make improvements learning model following the result of reflection and came up learning model that is ready for use. Pembelaja ran an integrated science that collaborated with the model problem-based learning can improve the skills of the scientific work of students and student learning outcomes effectively.[10] Learning can also use a guided inquiry learning model through experimental methods in improving learning outcomes in cognitive aspects and science process skills in students in learning science subject matter.[14]

Science learning can also use the Student Teams Achievement Division (STAD) learning model, which is cooperative learning that can spur students/students to actively collaborate, motivating students to support each other and help each other in mastering the abilities taught by educators and the team. Assisted Individualization (TAI) is a model by forming small, heterogeneous groups to help each other with other students who need help.[15] The science learning model can also use e-learning, namely all use or use of internet and web technology to create learning experiences and Blended learning is a learning approach that integrates traditional face-to-face learning and distance learning using online learning resources and various communication options. which teachers and students can use. The implementation of this blended learning allows the use of online learning resources, especially web-based ones, without leaving face-to-face activities. [16]

d) Learning science at Madrasah-Based Islamic Boarding School Tahfizh. 
The implementation of science learning, which is carried out by Madrasah Aliyah Yanbu'ul Qur'an Menawan Kudus has its character, both in terms of learning, religion-science integration, or science research guidance. Besides, there is also a science supervisor in each student's research using the Team Assisted Individualization method, namely by forming small groups in conducting research, so that in learning they help one another. Furthermore, to achieve maximum learning outcomes this method is collaborated with several other methods, including problem-based learning which aims to improve students' scientific work skills and student learning outcomes effectively, in which the implementation of each group of students makes a research proposal guided by a science supervisor until they get approval., then conduct a group research process guided by a science supervising teacher, at the end of the research each group presents the results of the research carried out. In implementing learning, educators are also trying to implement the four pillars of education [17] namely learning to know, learning to do, learning to be, and learning to be together or learning to live together. With this ability, it helps students to master how to acquire knowledge, apply the knowledge they have learned, and interact actively with fellow students, which makes students able to develop their potential and find their identity. [13] So that at the end of the lesson there will be at least one research in scientific research as well as strengthening the mastery of foreign languages in daily science and language learning in Islamic boarding schools with a division of days in language, namely Arabic day and English day.

The study of religious science integration at MA Yanbu'ul Qur'an Menawan Kudus from the results of research conducted by students is more likely to integrate existing Western theories related to the verses of the Qur'an followed by analyzing and explaining the unity and inconsistency between theory and verses of the Qur'an. Meanwhile, in carrying out scientific research, it uses a separate guideline called Science Innovation.[17]

\subsection{Integration of science learning}

\section{a) Integrated Thinking Science Learning.}

Mahzar argues that religion and science are not contradictory, both have a strong and inseparable integral relationship, where between science and religion according to him has a mutually reinforcing integrality relationship between the two, Mahzar sees the relationship between the two from the point of view of the Qur'an and The next hadith he made a concept with the term integral to Islamic science, namely the unification of natural and religious sciences as well as human and social sciences. Mahzar gave his argument about the very rapid scientific development in the golden age of Islamic civilization which at that time was developed by Muslim scientists. The concept of Islamic integralism according to Mahzar is divided into two levels, namely vertical which includes matter, energy, information, value, and sources of value and horizontally which includes humans as a microcosm, society as a mesocosmos, nature as a supracosmos, and God as a metacosmos. [6]

Bilgrami explained that science in Islam must be based on the concept of tawhid. The values of monotheism must be reflected in three main aspects of science, namely ethical and perspective aspects, historical and psychological aspects, and observative and experimental aspects. Science as a result of observation and experimentation on nature should not only stop at the apparent reality but also what is behind that reality. Science must be able to lead people to achieve happiness in this world and the hereafter. Science which is based on these three aspects was practiced by scientists during the first period of Islam which led to the glory and golden age of Islam.[18] 
Kuntawijaya said trying to prevent the Islamization of Muslims imitating external methods anything else. Islamization returns knowledge to its center, namely monotheism (monotheism). Kuntawijaya gave a new term with "Islamic knowledge" or "Islam as knowledge." For him, the Islamization of knowledge is a reactive response, while Islamic knowledge is proactive. In the process, the Islamization of knowledge is now irrelevant. Text loses context. Now, according to Kunto, Islamic knowledge is an intellectual movement that reconnects text to context (or from text to context), so that between text and context there is a correspondence.[19]

Agus Purwanto also argues that Islam and science can be categorized into three forms, namely the Islamization of Science, which is trying to make the great scientific discoveries of the 20th century, which mostly occurred in the West, can be in accordance with Islamic teachings, Islamic Saintification which means an effort to find the basis of science in a statements that are considered true in Islam and Islamic Science, namely an attempt to make the Qur'an and as-Sunnah as the basis for the construction of knowledge, as well as an attempt to make it capable of good integralization with modern science that has developed before[20]

Inspired by the ideas of scientists, in the next period a number of schools and madrasahs were concerned with natural science learning with the concept of a boarding school .[21] . Among them are MA Yanbu'ul Qur'an Menawan Kudus. Both schools apply experiential science learning centering with the concept of Islamic boarding schools and not only learn kauniyyah verses but students are able to memorize 30 juz of the Qur'an in addition to learning experiential knowledge. Furthermore, in realizing the maximum learning experience for students, of course, requires innovation by teachers who are supported by institutions or schools, both in terms of infrastructure and increasing the competence of the teacher concerned.

\section{b) Implementation of Science Learning in Madrasahs based on Islamic boarding schools tahfizh Al-Qur'an.}

Natural science learning that is integrated with Islamic scholarship is indispensable in the mastery of Islamic civilization in the future, while pesantren students who have a religious scientific foundation are often underestimated in their mastery of natural science, especially students from the tahfizh al-Qur'an pesantren. To overcome negative stigma in society and the development of schools in order to keep abreast of the times and trying to regain the glory of Islam that had been achieved by the managers of Islamic educational institutions namely MA Yanbu'ul Qur'an Menawan-based schools tahfizh Qur'an has done a new innovation by developing a boarding school with a modern design, by developing the learning of the tahfizh al-Qur'an pesantren which also teaches science learning over time also strengthens it by using Arabic and English communication as a supporting tool.

To find out in depth about what has been done by MA Yanbu'ul Qur'an Menawan Kudus, the researchers collected data about learning support that had been prepared by the two Islamic education institutions in order to realize their vision and mission, which from its contents can be concluded as follows, namely the formation of generations Qur'anic that is elegant, intellectual and technology literate. These constructions include the design of foreign language construction as a very supportive aspect of learning, the design of institutional management which is directed at managing a modern system model, preparing facilities and infrastructure capable of supporting learning, preparing appropriate educational systems and methodologies in order to help the learning process, preparing human resources, including teachers, 
laboratory assistants and education personnel who have and acceptance of well-selected students, curriculum design, and science learning design.

Science lessons conducted at MA Yanbu'ul Qur'an Menawan, namely; 1. Provide guided research modules to students. 2. The application of Arabic and English in everyday life. 3. The research module in science subjects uses the school's module. 4. The results of science learning are expected to produce a group of guided research products. 5. The pattern of integration of religious and science learning refers to the Islamization pattern of science.[17] After studying the design and learning patterns of the two Islamic educational institutions, the researcher tries to draw conclusions from the management system as described above, especially about the science learning model that is sourced with real data from both of them to draw conclusions as a science learning model at the institution.

\section{Conclusion}

The results of research at MA Yanbu'ul Qur'an Menawan Kudus are learning activities to science learning uses guided learning by science teachers. Research was carried out by each group of students with a religion-science integration system following the pattern of Islamization of science. Meanwhile, science learning is carried out under the guidance of a science teacher with a research target of one group of one research with a religion-science integration system following the scientific scientific pattern. This pattern is a development of the science integration idea of scientists, one of which is Agus Purwanto. The learning of science in the madrasa is then integrated with the uniqueness and excellence in the field of memorizing the Qur'an for its students. From the science learning model, it is hoped that it will become a model for the development of the pesantren tradition in producing tafaqquh fiddin scholars, hafizh Al-Qur'an who are not only capable in the field of syar'i science but also master technology, especially in the field of natural science.

\section{References}

[1] Nurul Anam, "Al-Qur'an dan Hadits: dialektika sains-teknologi dan ilmu agama," al 'Adalah, vol. 16, no. 2, pp. 213-226, 2012.

[2] Nur Wahyu Hermawati, "Konsep Ilmu Berlandasakan Tauhid Ismail Raji Al-Faruqi Serta Implikasinya di Dunia Pendidikan,” at Ta'dib, vol. 10, no. 02, pp. 383-402, 2015.

[3] Hermawan, "Interaksi Islam dan Sains: Studi Historis-Fenomenologis di SMA Trensains Sragen," Cakrawala, vol. XII, no. 2, pp. 101-112, 2017.

[4] A. Romdhoni, "Tradisi Hafalan Qur' an di Masyarakat Muslim Indonesia," J. Qur'an Hadith Stud., vol. 4, no. 1, pp. 1-18, 2015.

[5] S. Kurniawan, "Reconcile the religion and science education management in islam," Ta'dib, vol. 20, no. 1, pp. 103-129, 2015.

[6] W. Khoirul, "Relasi Sains dan Agama Perspektif IAN G. Barbour dan Armahedi Mazhar," Lil, Rahmatan Journal, Alamin Educ. Peace Stud. Islam., vol. 1, no. 1, pp. 29-38, 2018.

[7] J. Fakhri, "Sains dan Teknologi dalam al-Qur'an dan Implikasinya dalam Pembelajaran," Ta'dib, vol. XV, no. 01, pp. 121-142, 2010.

[8] Depdiknas, Kamus Besar Bahasa Indonesia. Jakarta: Balai Pustaka, 2002. 
[9] S. Muhibbin, Psikologi Belajar. Jakarta: Rajawali Pres, 2009.

[10] P. Rahayu, S. Mulyani, and S. S. Miswadi, "Pengambangan Pembelajaran IPA Terpadu dengan Menggunakan Model Pembelajaran Problem Base Melalui Lesson Study," J. Pendidik. IPA Indones., vol. 1, no. 1, pp. 63-70, 2012.

[11] A. Asyhari, "Profil Peningkatan Kemampuan Literasi Sains Siswa Melalui Pembelajaran Saintifik,” J. Ilm. Pendidik. Fis. Al-Biruni, vol. 4, no. 2, p. 179, 2015.

[12] T. Kennet, Handbook Pengajaran dan Pembelajaran Sains. Bandung: LPIP, 2015.

[13] J. A. Wahab, Belajar dan Pembelajaran Sains. Bandung: Pustaka Reka Cipta, 2013.

[14] Y. Subekti and A. Ariswan, "Pembelajaran Fisika dengan Metode Eksperimen untuk Meningkatkan Hasil Belajar Kognitif dan Keterampilan Proses Sains The Physics Learning with Experimental Methods to Increase Cognitive Aspects of Learning Outcomes and Science Process Skills," J. Inov. Pendidik. IPA, vol. 2, no. 2, pp. 252 261, 2016.

[15] K. Ari Purwa, "Implementasi Model Pembelajaran Student Teams Achievement Division (STAD) dan Team Assisted Individualization (TAI) ditinjau dari Kemampuan Spasial Siswa," Al-Jabar J. Pendidik. Mat., vol. 08, no. 02, pp. 135-144, 2017.

[16] I. Wahyudi, "Pengembangan Program Pembelajaran Fisika SMA Berbasis e - Learning dengan Schology the Development of Physics Learning Program Based on e-Learning With Schoology," J. Ilm. Pendidik. Fis. Al-Biruni, vol. 06, no. 2, pp. 187-199, 2017.

[17] Mr. Yuniar, "Direct interview," 2020, p. 14 March.

[18] H. H. \& syed A. A. Bilgrami, "Konsep Universitas Islam dan Islamisasi Ilmu Pengetahuan Konsep Universitas Islam," in The Concept of Islamic University. Terj. Machmud Husein, Yogjakarta: Tiara Wacana Yogya, 1989, p. xxxii-115.

[19] M. Z. Bahri, "Expressing Political and Religius; Religion-Science Relations in Indonesian Muslim Thinkers 1970-2014," Al-Jāmi 'ah J. Islam. Stud. Islam. Stud. -, vol. 56, no. 1, pp. 155-186, 2018.

[20] M. Y. Yusuf, "Epistemologi Sains Islam Perspektif Agus Purwanto," Anal. J. Stud. Keislam., vol. 17, no. 1, p. 65, 2017.

[21] M. Ahmad, "Kontruksi Kurikulum Sains Islam Keindonesiaan ( Integrasi Islam , Sains Kealaman , Sains Humaniora dan Keindonesiaan)," Edukasi, vol. 16, no. 1, pp. 80-93, 2018. 